\title{
Peran Website Desa dalam Peningkatan Partisipasi Masyarakat Desa Nglanggeran dan Desa Girijati Kabupaten Gunungkidul
}

\author{
The Role of Village's Website in Increasing Community Participation \\ at Nglanggeran and Girijati Village Gunungkidul District
}

\section{Ganda Sibarani $^{1}$}

\begin{abstract}
Abstrak: Penelitian ini bertujuan mendeskripsikan hubungan antara variabel terpaan informasi website terhadap variabel partisipasi masyarakat dalam pembangunan desa yang memanfaatkan sistem informasi desa (SIDA) melalui website desa agar ragam datainformasi kebijakan desa dapat dimanfaatkan secara cepat dan mudah diakses di Desa Nglanggeran dan Desa Girijati, Kabupaten Gunungkidul. Metode penelitian adalah Mix methods sequential explanatory designs dengan teknik penyebaran data kuesioner, dilanjut dengan wawancara mendalam dan observasi. Data yang diperoleh dianalisis secara kuantitatif statistik non parametrik. Hasil analisis statistik tersebut selanjutnya dibawa kembali ke lapangan sebagai bahan dasar wawancara dan dianalisis kualitatif untuk membangun konseptual pengetahuan peran website berdasarkan perspektif partisipatori. Hasil penelitian menunjukkan bahwa tidak ada pengaruh signifikan antara desa yang mengelola website dengan baik dan tidak. Keberadaan website desa pada level penyelenggaraan pemerintahan cukup efektif namun pada peningkatan partisipasi masyarakat, website desa belum dapat menimbulkan efek kognitif, afektif dan konatif pada peningkatan kesadaran dalam pembangunan dan partisipatif. Hal ini disebabkan beberapa faktor seperti nilai berita, konsistensi dan variasi program SIDA, konektivitas internet dan kepemilikan perangkat akses, modal sosial, budaya lisan, dan misleading kebijakan Pemerintah Daerah. Untuk memaksimalkan website desa, masyarakat perlu diberikan penguatan jurnalisme warga agar peran aktif masyarakat dalam penyajian berita dan menggiatkan komunikasi warga dengan Pemerintah Desa.
\end{abstract}

Kata kunci: TIK, Partisipasi Masyarakat, Jurnalisme Warga

\begin{abstract}
This research aims to describe the association between the website information exposure variables to the community participation variable in village development that utilizes the village information system (SIDA) through the village website so that various village policy data can be used quickly and easily accessed in Nglanggeran Village and Girijati Village, Regency Gunungkidul. The research method is mix methods sequential explanatory designs with questionnaire data distribution techniques, followed by in-depth interviews and observations. The data obtained were analyzed quantitatively with non-parametric statistics. The results of the statistical analysis were then brought back to the field as a basis for interviews and were analyzed qualitatively to build a conceptual knowledge of the role of the website based on a participatory
\end{abstract}

\footnotetext{
${ }^{1}$ Magister Perencanaan Wilayah dan Kota, Universitas Gadjah Mada
} 
perspective. The results showed that there was no significant influence between villages that managed the website well and not. The existence of village websites at the level of government administration is quite effective but at increasing community participation, village websites have not been able to cause cognitive, affective and conative effects on increasing awareness in development and participation. This is due to several factors such as the value of news, consistency and variety of SIDA programs, internet connectivity and ownership of access devices, social capital, oral culture, and misleading local government policies. To maximize the village website, the community needs to be given strengthening citizen journalism so that the community plays an active role in presenting news and intensifying community communication with the village government.

Keywords: ITC, Community Participation, Citizen Journalism

\section{PENDAHULUAN}

Data adalah fakta di lapangan yang dapat berupa kejadian, peristiwa, fenomena alam yang berlangsung di masyarakat. Pendit (1992), menyatakan bahwa data adalah hasil observasi langsung terhadap suatu kejadian yang merupakan perlambangan yang mewakili objek atau konsep dalam dunia nyata. Menurut Terry (1962), Informasi merupakan data penting dan bernilai, memiliki pengetahuan atau atribut yang digunakan pada pengambilan keputusan. Data akan berubah menjadi informasi apabila keberadaannya mampu mengubah seseorang untuk melakukan suatu tindakan. Data diperlukan dalam perencanaan pembangunan karena data akurat dan berkualitas mempengaruhi proses pengambilan dan penetapan kebijakan. Sedangkan, Davis (1974) mengatakan informasi adalah data yang telah diolah menjadi sebuah bentuk penting bagi penerima dan mempunyai nilai nyata atau dapat dirasakan dalam keputusan sekarang atau yang akan datang. Jadi, informasi adalah data yang telah diolah untuk digunakan dalam proses pengambilan keputusan dengan menambahkan pengetahuan secara akurat, tepat waktu, dan relevan.

Kualitas data dan informasi yang tersedia dapat mempengaruhi tingkat keberhasilan program pembangunan di suatu wilayah pemerintahan. Pemerintah saat ini sedang mengupayakan pengembangan basisdata kependudukan yang lebih baik. Pengambilan kebijakan di tingkat pusat sering berdasarkan pada basisdata yang tidak akurat yang berasal dari Pemerintahan di bawahnya. Desa sebagai wilayah administrasi terdepan menjadi tumpuan utama untuk membangun basisdata akurat. Untuk itu, dibutuhkan suatu media komunikasi pembangunan Sistem Informasi Desa (SIDA) berupa website yang mempermudah aparat desa untuk menyelenggarakan tugas pelayanan, mempresentasikan hasil kinerja, mempromosikan potensi dan produk unggulan desa. Dengan demikian, datadata yang terkumpul dapat diolah menjadi data yang bernilai dan siap digunakan.

Teknologi informasi merupakan teknologi yang mengelola data menjadi informasi dimana proses transfer data-informasi terjadi dalam batas ruang dan waktu (Indrajit, 2011). Pemanfaatan Teknologi Komunikasi dan Informasi di pedesaan yang mulai dikembang masih mengalami banyak kendala seperti masih kurang tersedianya program infrastruktur, manajemen, komunikasi, wilayah territorial yang terpencil, literasi TIK, dan kesadaran masyarakat yang kurang (Amin, 2018). Pelayanan masyarakat dengan mengimplementasikan e-governance masih memerlukan waktu, alih teknologi dan kesiapan SDM agar dapat dimanfaatkan untuk kemudahan pelayanan masyarakat (Anggrahini, dkk, 2008). Pemerintah saat ini sedang mengembangkan pemanfaatan basisdata pedesaan untuk mengatasi kesalahan pengambilan kebijakan di tingkat pusat yang sering berdasarkan pada basisdata yang tidak up to date dan akurat yang berasal dari pemerintahan di bawahnya melalui website desa. Website diyakini mampu mempermudah aparat desa dalam mempresentasikan hasil kinerja ataupun produk- 
produk yang ada dalam desa, mempermudah pekerjaan, merubah data mentah menjadi suatu data bernilai dan siap digunakan.

Sepanjang pengetahuan Peneliti, belum ada penelitian di Indonesia yang fokus meneliti hubungan antara terpaan konten website desa dengan tingkat partisipasi masyarakat dalam konteks pembangunan desa. Namun, terdapat penelitian sejenis yang mengindentifikasi hubungan antara konseptual komunikasi pembangunan dengan konseptual perencanaan pembangunan masyarakat pedesaan. Andi J. Kasma (2019), menganalisis partisipasi masyarakat terhadap pembangunan pada desa terdekat dan terluar dari ibukota kabupaten Wajo, Sulawesi Selatan dan apa alasan yang membedakan antara partisipasi masyarakat yang terjadi pada kedua desa tersebut. Hasil penelitian menunjukkan bahwa partisipasi masyarakat dalam pembangunan desa kedua desa berupa proses perencanaan, pelaksanaan, dan pengawasan pembangunan desa, faktor yang membedakan partisipasi masyarakat dalam pembangunan kedua desa adalah kepemimpinan, tingkat pendidikan, mata pencarian, dan peranan generasi muda. Bentuk partisipasi dalam pembangunan desa yaitu tahap perencanaan berupa keikutsertaan masyarakat dalam menghadiri rapat perencanaan pembangunan dan aktif memberi masukan dan saran.

Pemanfaatan Sistem Informasi Desa (SIDA) diharapkan dapat mendorong peningkatan kinerja Pemerintah Desa menjadi lebih baik. Pemerintahan Desa sebagai dalam tata pemerintahan sering mengeluhkan soal pelayanan kepada pemerintahan internnya maupun pelayanan publik kepada warganya karena keterbatasan sumber daya yang dimiliki, kapabilitas dan kapasitas pelayanan Pemerintah desa masih seadanya. Keadaan tersebut mendorong Pemerintah kabupaten Gunungkidul melakukan percepatan dalam mewujudkan good governance dan otonomi desa melalui berbagai upaya penataan baik di level sistem, kelembagaan maupun sumber daya manusia perangkat desa.

\section{METODE}

Penelitian ini berusaha mencari hubungan Peran Website Desa dalam Peningkatan Partisipasi Masyarakat Desa dengan menggunakan mix methods yang menggabungkan dua bentuk penelitian kualitatif dan penelitian kuantitatif. Jenis penelitian adalah field research dimana peneliti menggunakan jenis penelitian kombinasi karena menghasilkan fakta komprehensif dalam memecahkan masalah dan kebebasan untuk menggunakan semua alat pengumpul data sesuai dengan jenis data yang dibutuhkan. Creswell (2010), menyatakan bahwa penelitian mix methods, yaitu suatu langkah penelitian dengan menggabungkan dua bentuk pendekatan dalam penelitian, yaitu kualitatif dan kuantitatif.

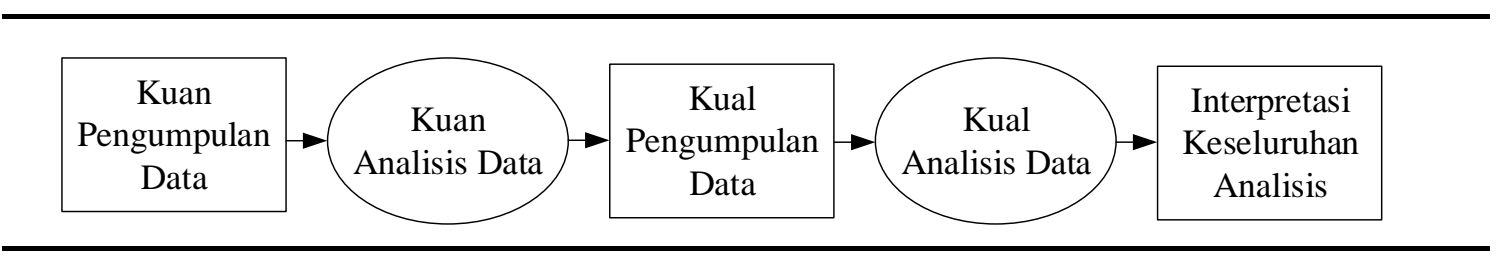

Gambar 1. Desain Penelitian Sequential Explanatory

Jenis desain penelitian yang digunakan adalah sequential explanatory designs dimana strategi yang diterapkan dengan pengumpulan dan analisis data kuantitatif pada tahap pertama yang diikuti oleh pengumpulan dan analisis data kualitatif pada tahap kedua yang dibangun berdasarkan hasil awal kualitatif (Creswell, 2010). Penelitian eksplanatori sekuensial bertujuan untuk menguji suatu teori atau hipotesis untuk memperkuat atau menolak teori atau hipotesis hasil penelitian yaitu ada hubungan positif antara paparan media website desa terhadap peningkatan partisipasi masyarakat desa. 
Metode kuantitatif berperan untuk memperoleh data kuantitatif yang terukur yang dapat bersifat deskriptif, komparatif dan asosiatif dan metode kualitatif berperan untuk membuktikan dan memperdalam data kuantitatif yang telah diperoleh pada tahap awal (Sugiyono, 2008).

Desain pada Gambar 1bertujuan untuk membantu analisis data kualitatif menjelaskan secara detail mengenai data hasil kuantitatif yang diperoleh lebih awal yang dibawa ke lapangan untuk dikonfirmasi kebenarannya melalui teknik wawancara mendalam dan observasi.

Jenis data dalam penelitian ini adalah data kuantitatif dan kualitatif. Penyebaran kuesioner dilakukan dengan membagikan kuesioner kepada responden dengan teknik purposive sampling. Syarat responden usia di atas 18 tahun dan paling tidak pernah sekali mengakses website desa sehingga diperoleh sebanyak 74 responden di desa Nglanggeran dan sebanyak 62 responden di desa Girijati. Untuk pengumpulan data kualitatif dilakukan wawancara mendalam dengan pertanyaan berjumlah 4 pertanyaan, namun saat proses wawancara dapat dikembangkan sesuai kebutuhan. Dari wawancara yang telah dilakukan selama kurang lebih 3 minggu pada masa pandemi covid-19, diperoleh 15 narasumber di desa Nglanggeran dengan rincian 11 laki-laki 4 perempuan dan di desa Girijati diperoleh 8 narasumber dengan 6 laki-laki 2 perempuan. Wawancara dilakukan dengan menanyakan apakah calon narasumber pernah paling tidak sekali mengakses website desa dan pernah mengikuti salah satu kegiatan yang dilakukan oleh warga desa. Dengan demikian, diperoleh jawaban yang lebih komprehensif mengenai peran website desa dalam kehidupan masyarakat desa.

Penelitian ini menggunakan dua (2) konsep variabel yaitu paparan informasi website desa dan partisipasi masyarakat dimana variabel paparan informasi website desa sebagai variabel independen dan partisipasi masyarakat sebagai variabel dependen. Variabel-variabel tersebut diukur dalam instrument penelitian dengan kuesioner yang telah ditentukan dengan menggunakan skala likert. Untuk setiap jawaban diberikan skor penilaian dan skor yang diperoleh mempunyai pengukuran ordinal. Variabel independen dalam penelitian ini adalah Terpaan Informasi Website (X) dan variabel dependen adalah tingkat Partisipasi Masyarakat (Y). Definisi operasional variabel penelitian adalah sebagai berikut:

Tabel 1. Definisi Operasionalisasi

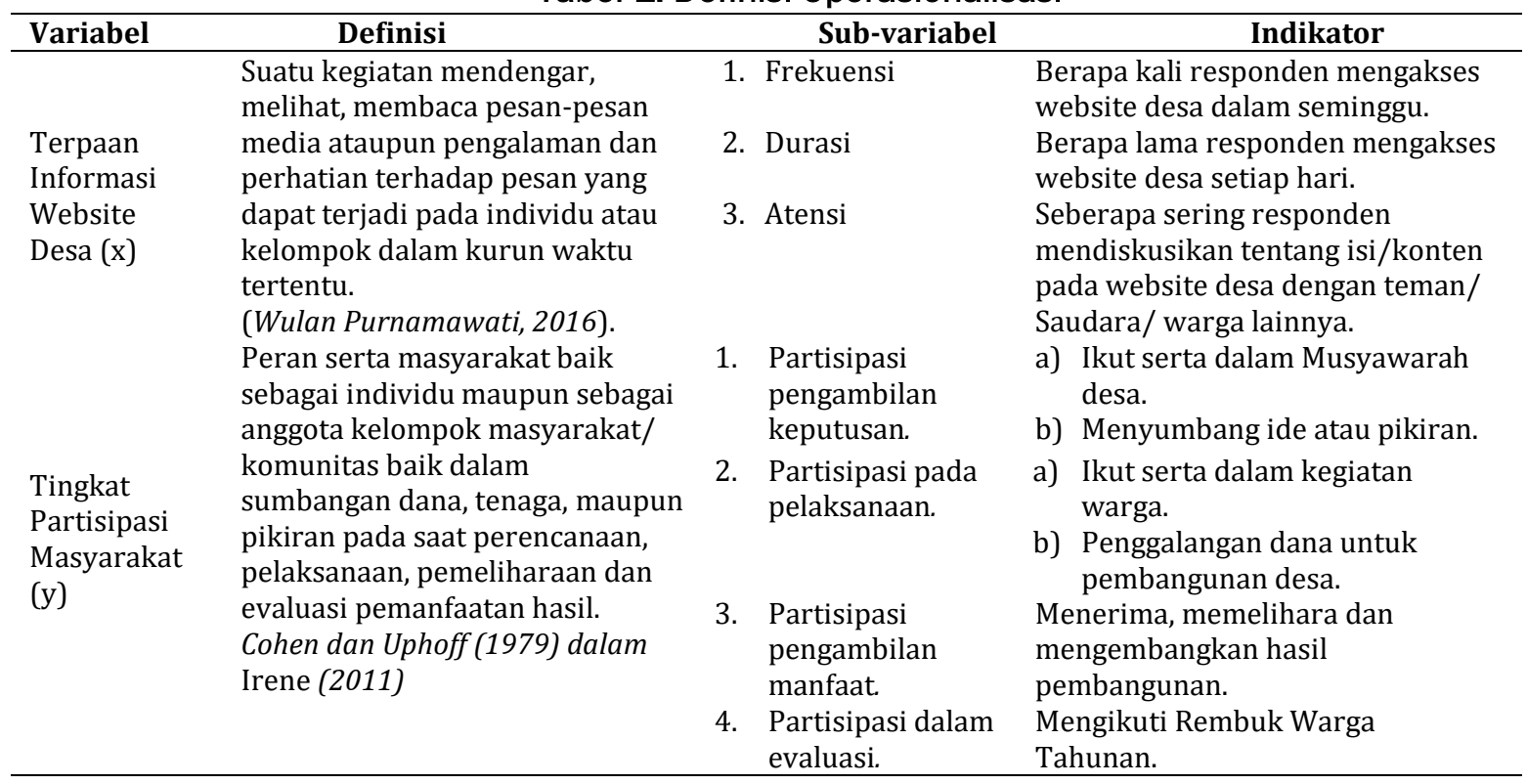

Sumber: Peneliti, 2020 


\section{TEMUAN DAN PEMBAHASAN}

\section{Analisis Kuantitatif}

Ruang lingkup spasial penelitian ini adalah desa Nglanggeran dan desa Girijati Kabupaten Gunungkidul. Kedua desa ini dipilih karena merepresentasikan kategori desa mandiri dan desa berkembang berdasarkan Indeks Desa Membangun (IDM) dan karakteristik wilayah yang berbeda dan pengelolaan website yang kontras di antara kedua desa.

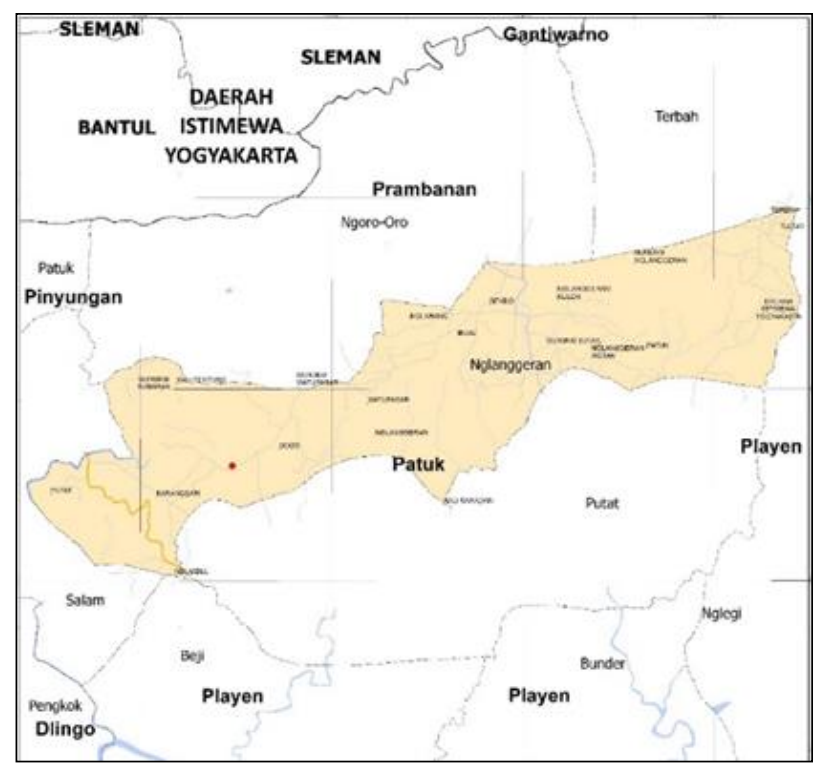

Gambar 2. Peta Desa Nglanggeran.

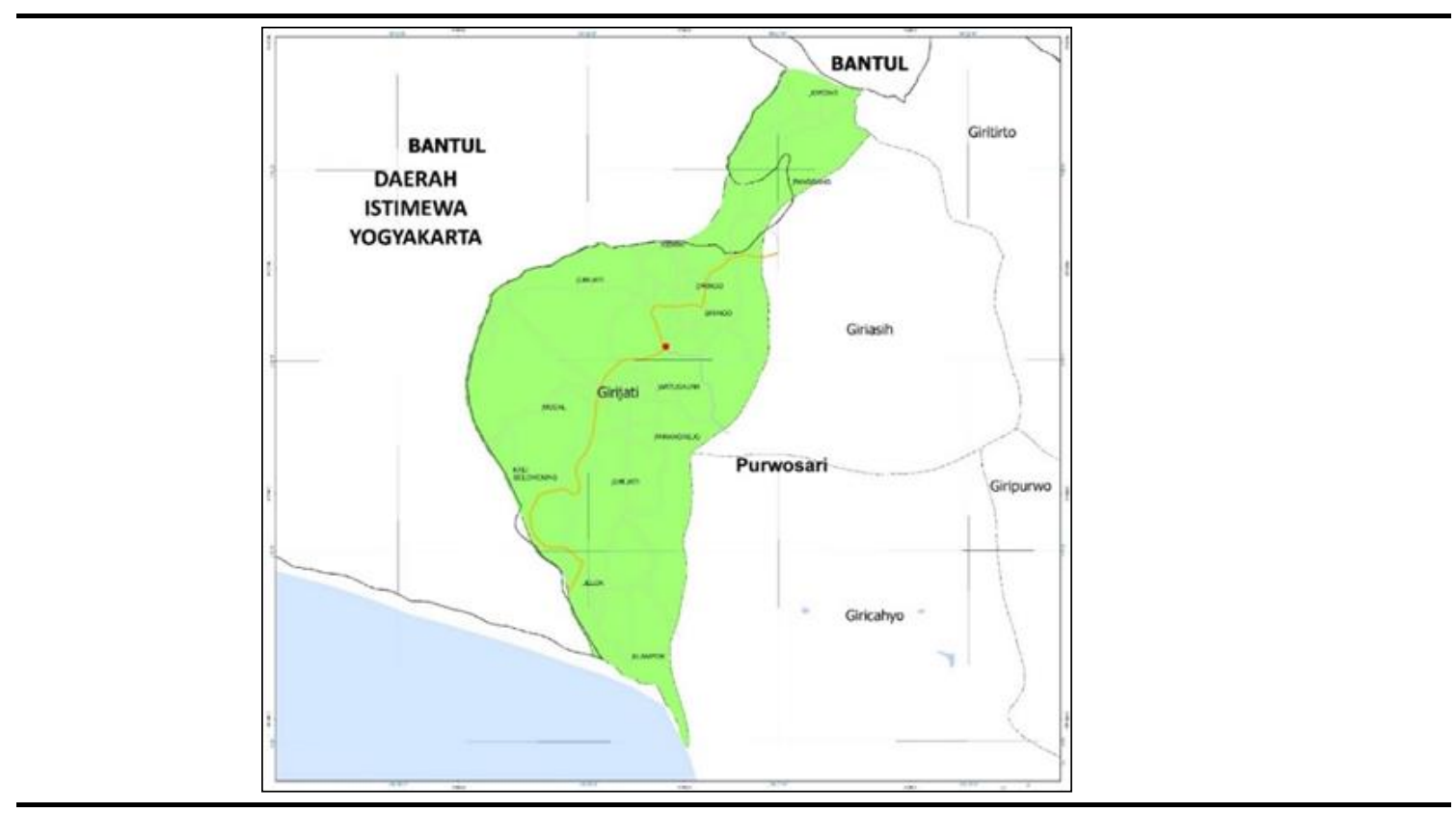

Gambar 3. Peta Desa Girijati 
Pada penelitian ini, variabel independen Terpaan Informasi Website (X) mempunyai 3 butir sub variabel dan 3 pertanyaan dan variabel dependen Tingkat Partisipasi Masyarakat (Y) mempunyai 4 sub variabel dengan 6 pertanyaan dengan rincian sebagai berikut:

Tabel 2. Penjabaran Sub Variabel

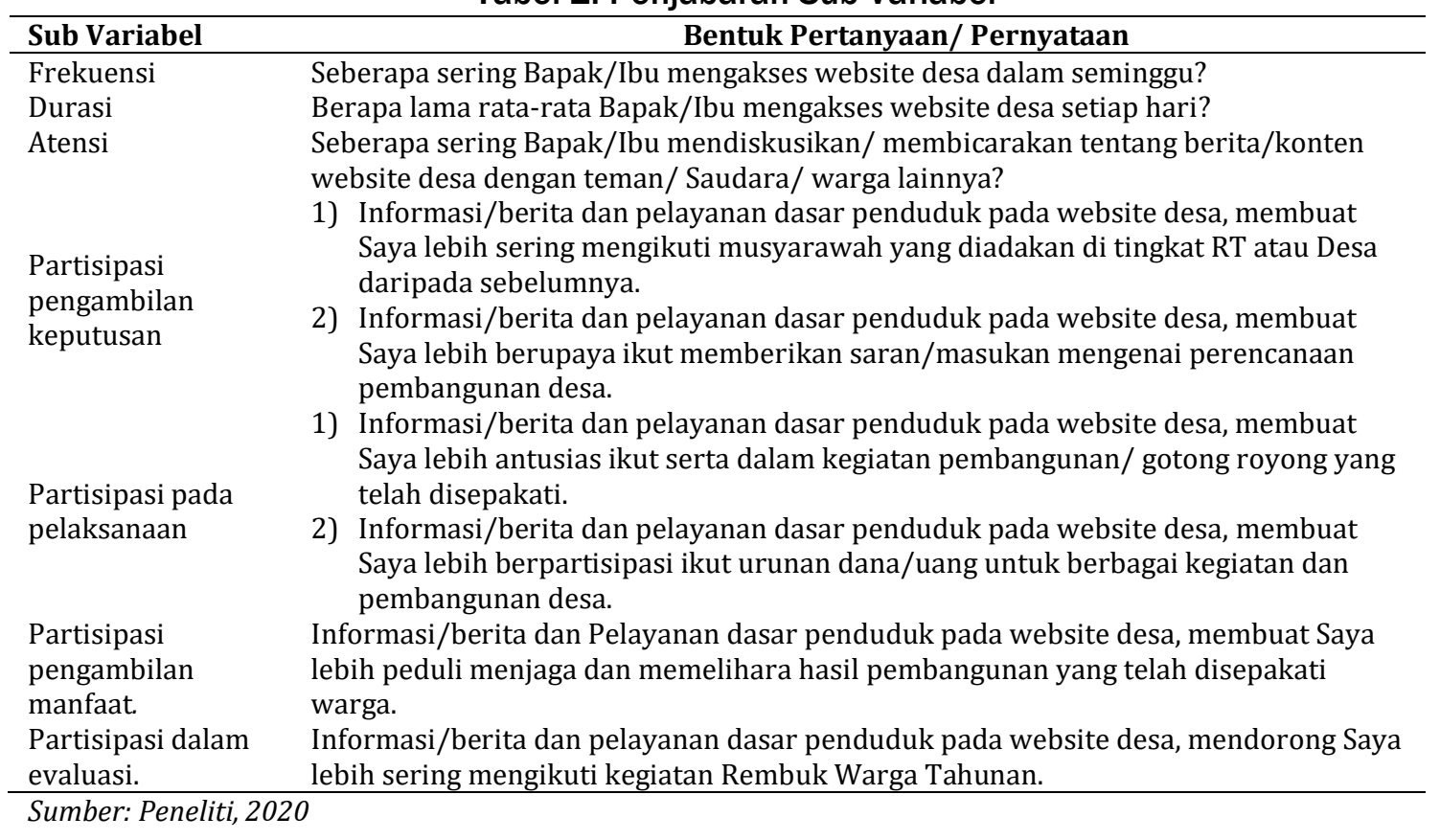

Dari kuesioner yang dikumpulkan, kemudian diuji validitas dan reliabilitas masingmasing variabel sehingga diperoleh hasil variabel $X$ dan variabel $Y$ valid dan reliabel pada masing-masing desa. Selanjutnya dilakukan uji crosstab, uji Chi Kuadrat Person, dan menganalisis setiap Item pertanyaan variabel pada kedua desa. Hipotesis yang digunakan adalah:

Ho: Tidak ada hubungan antara Terpaan Informasi Informasi Website Desa dengan Peningkatan Partisipasi Masyarakat.

H1: Ada hubungan antara Terpaan Informasi Website Desa dengan Peningkatan Partisipasi Masyarakat.

Dari hasil analisis uji Crosstab dan Chi Square dengan menggunakan perangkat lunak SPSS diperoleh hasil bahwa tidak ada hubungan antara Terpaan Informasi Website Desa dengan Peningkatan Partisipasi Masyarakat.

\section{Analisis Kualitatif}

Wawancara mendalam dilaksanakan dengan menggunakan bahan wawancara yang bersumber dari hasil analisis kuantitatif yaitu mengapa dan apa yang menyebabkan tidak ada hubungan antara terpaan informasi website dengan peningkatan partisipasi masyarakat dan apa faktor penyebabnya. Dari hasil analisis dan interpretasi data, diperoleh gambaran kedua website desa umumnya memiliki dua jenis konten informasi dalam website desa yaitu:

1. Informasi Statis Website Desa

Informasi statis adalah jenis informasi yang relatif tidak berubah/tidak perlu diubah dalam waktu yang relatif lama. Informasi ini tidak bersifat seperti berita yang harus diperbarui setiap hari dan umumnya berupa data berkala. 
2. Informasi Dinamis Desa

Informasi dinamis desa adalah konten informasi yang akan/harus diperbarui secara berkala meliputi informasi agenda desa, informasi laporan desa terbaru, informasi pelayanan publik desa terkini, informasi produk usaha desa, dan opini atau warga.

Konten website desa umumnya adalah berita desa, informasi kegiatan, pelaksanaan kegiatan baik yang berasal dari pemerintah kabupaten, kecamatan, atau desa itu sendiri. Berita desa ditampilkan berupa berita langsung dengan penulisan berita langsung dilakukan dalam format piramida terbalik. Informasi yang paling penting dituliskan pada bagian awal, sedang rincian informasi dituliskan pada bagian sesudahnya. Berita langsung ditulis dengan lugas, ringkas, dan langsung mengungkapkan persoalan yang dilaporkan yang terdiri dari 100-200 kata.

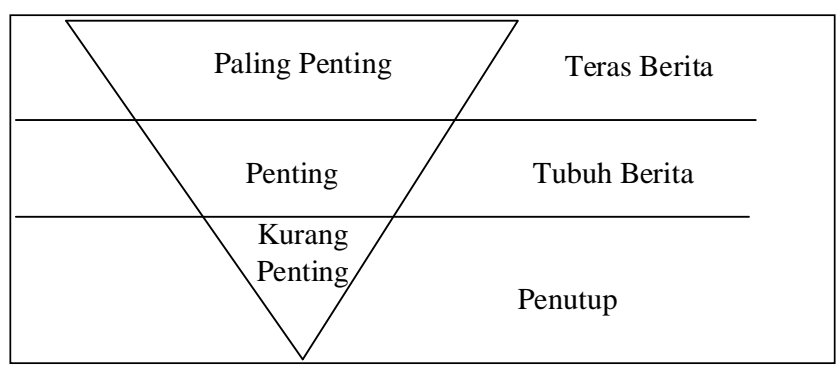

\section{Gambar 4. Karakteristik Konten Informasi kedua website desa}

Dari karakteristik konten artikel/informasi yang dianalisis dapat disimpulkan bahwa artikel/informasi berita pada website desa masih bersifat aktualitas dimana artikel menarik perhatian pembaca, masih hangat dibicarakan, dan belum lama/sedang terjadi. Berdasarkan jenis berita, informasi pada website desa termasuk kategori soft news yang berkarakter berita ringan, fleksibel, tidak ketat, struktur tidak kaku, terkadang subjektif, cenderung menghibur, dan laporan peristiwa yang mengangkat aspek kehidupan desa. Dari sisi waktu, pemberitaannya terkadang tertunda karena bukan berarti tidak penting namun lebih kepada masalah waktu operasional yang harus diolah dan biasanya dilaporkan pada jam kerja Pemerintah desa.

\section{Efektivitas Website Desa sebagai Media Informasi Pembangunan di Desa Nglanggeran dan Desa Girijati}

Pada penelitian ini, efektivitas media komunikasi website desa meliputi efek kognitif yaitu terjadi perubahan perilaku atas pemahaman tentang sesuatu dari yang tidak tahu menjadi tahu pada objek yang diperkenalkan. Efek afektif yaitu perilaku di mana individu mempunyai kecenderungan untuk yakin atau percaya terhadap suatu objek, dan efek behavioral/konatif yaitu perubahan berperilaku atau melakukan sesuatu sesuai dengan yang diharapkan komunikator dimana ada tindakan/ perilaku nyata terhadap objek (Alvonco, 2014). Hasil analisis menunjukkan bahwa efektivitas website desa pada efek kognitif pada masyarakat Nglanggeran dan Girijati telah terbentuk atau timbul kesadaran/ pemahaman baru yang diakibatkan oleh terpaan berita di website desa. Konten berita/ artikel pada website desa saat ini masih bersifat perpanjangan tangan Pemerintah Pemerintah atau berita yang kejadiannya sudah diketahui lebih dulu oleh masyarakat. Website desa mempermudah pelayanan pada level administrasi pemerintahan, informasi pariwisata desa, pelayanan kesehatan, kegiatan kepemudaan, dan informasi potensi desa 
namun belum dapat mengedukasi warga yang sebagian besar merupakan petani atau buruh yang tidak terlalu membutuhkan informasi pembangunan dan rata-rata berpendidikan SMP dan SMA.

Efek kognitif dalam penelitian ini berkaitan dengan keberadaan website desa seperti memperkaya informasi dan pemahaman tentang pelayanan publik, menjadi lebih terampil dalam menggunakan atau bernavigasi untuk mengecek informasi yang mendalam tentang pembangunan di desa Nglanggeran dan Girijati dan dapat menyampaikan pendapat atau komentar melalui kolom komentar tersebut, baik berupa saran bahkan kritik. Hal ini menjadi keunggulan media internet untuk membantu warga yang tidak berani/segan mengungkapkan suatu pesan secara langsung sehingga terbantu untuk mengungkapkan secara tertulis.

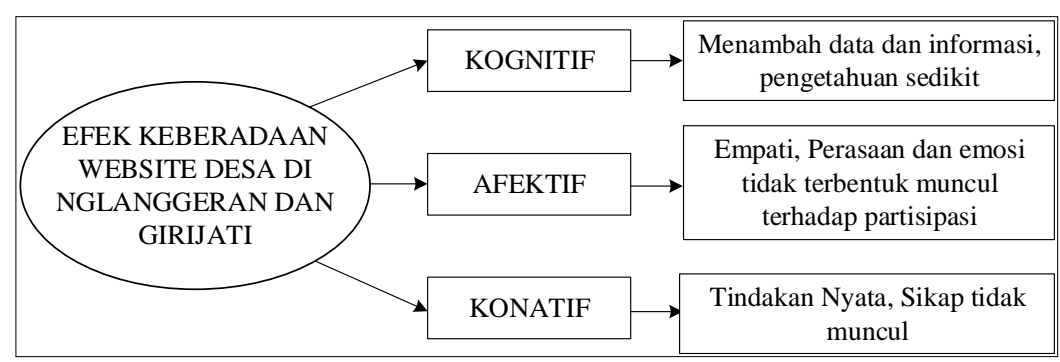

\section{Gambar 5. Efek konten Informasi pada Website Desa}

Sedangkan pada efek afektif berhubungan dengan perasaan, persepsi dan attitude (sikap), terpaan konten/berita pada website desa hanya terjadi pada sedikit orang dan tidak berpengaruh terhadap peningkatan partisipasi masyarakat secara luas. Peningkatan rasa empati atau kepedulian terhadap kondisi dan aktivitas pembangunan hanya dialami oleh individu yang berhubungan dengan aktivitas Pemerintahan Desa seperti Perangkat Desa. Hal ini dipengaruhi oleh sifat pekerjaan itu sendiri yang mengharuskan individu tersebut melaksanakan tugas dan fungsinya di tengah-tengah masyarakat. Selain itu, pesan pada jenis konten/artikel website tidak mempunyai pengaruh besar (magnitude) bagi masyarakat untuk meningkatkan perhatian atau membentuk sikap kesadaran masyarakat dalam berpartisipasi.

Pada efek behavioral/ konatif yang berhubungan dengan perilaku nyata seperti tindakan atau kebiasaan yang diharapkan muncul akibat dari pengaruh terpaan konten website desa terhadap peningkatan partisipasi masyarakat tidak ada. Dari hasil interpretasi, perilaku yang mengarah pada efek behavioral belum muncul seperti proses sikap, pengalaman dan meniru seorang tokoh di masyarakat yang dipengaruhi oleh terpaan website desa dan individu di masyarakat belum terlibat secara sukarela dalam perubahan pembangunan, kehidupan dan lingkungan desa. Hal ini dipengaruhi oleh kualitas konten berita yang tidak menarik, tidak signifikan, dan kurang berdampak dan belum mengedukasi masyarakat desa sehingga belum mampu membangun kesadaran dan pelaksanaan partisipasi pembangunan.

Dapat disimpulkan bahwa website nglanggeran-patuk.desa.id dan girijatipurwosari.desa.id belum efektif sebagai media komunikasi massa untuk meningkatkan peran partisipasi masyarakat desa secara personal maupun komunitas untuk berinisiatif dan menggunakan pilihan untuk berpartisipasi dalam pembangunan desa. Namun, cukup efektif dalam menyebarkan informasi pelayanan publik. 


\section{Faktor-Faktor yang Mempengaruhi}

Dari interpretasi keseluruhan, terdapat faktor-faktor yang mempengaruhi mengapa keberadaan website desa tidak berpengaruh terhadap proses peningkatan partisipasi masyarakat. Faktor-faktor tersebut dapat dibedakan dalam dua klasifikasi, yaitu:

Faktor Internal

1) Nilai Berita

Konten website desa seharusnya memiliki nilai dan kualitas lebih. Nilai konten yang dibutuhkan adalah konten yang mampu membawa perasaan warga desa ikut terbawa dan mampu menyampaikan pesan implisit dari konten yang disajikan. Konten pada website desa belum disajikan dengan menggunakan prinsip $5 \mathrm{~W}+1 \mathrm{H}$ dan gaya penulisan berita cenderung apa adanya, tidak menggunakan How-To dan juga belum memberikan edukasi berupa Tips \& Trik pada penulisan artikel berita.

Secara umum, artikel berita pada website desa nglanggeran-patuk.desa.id dan girijati-purwosari.desa.id merupakan pelaporan kegiatan yang benar terjadi atau kegiatan dalam kehidupan masyarakat. Namun, ketika diberitakan dalam bentuk reportase, nilai-nilai berita tidak muncul secara bersamaan seperti aktualitas, kedekatan antara peristiwa dengan masyarakat, dampak yang diharapkan, tokoh atau objek peristiwa, keunikan berita, dan sisi humanis berita yang tidak terpadu pada satu artikel berita. Nilai berita artikel pada website desa pun belum menjadi ukuran dalam menentukan layaknya berita (newsworthy) karena target pembaca adalah warga desa dengan tingkat pendidikan rata-rata SMP dan SMA.

\section{2) Konsistensi dan Variasi Program SIDA}

Program Sistem Informasi Desa (SIDA) merupakan amanat dari Undang-Undang Desa pasal 86 yang menyatakan bahwa Desa berhak mendapatkan akses informasi melalui sistem informasi desa yang meliputi data desa, data pembangunan desa, kawasan perdesaan, serta informasi pembangunan desa. SIDA dirancang untuk memaduserasikan antara data, informasi, dan pengambilan kebijakan untuk membantu Pemerintah Desa dalam mendokumentasikan data-data milik desa guna, menyajikan informasi tentang kemiskinan di desa mulai dari sistem pendataan keluarga, sistem informasi perencanaan dan penganggaran, dan sistem informasi data potensi desa.

Namun, dalam prakteknya data dan informasi pada website desa yang tersaji pada feature statistik dan data desa jarang diperbaharui dan berita yang disajikan adalah jenis berita peristiwa atau kegiatan. Padahal semestinya, Sistem Informasi Desa menjadi tools penyelenggaraan kinerja pemerintah desa bukan menambah tugas perangkat desa dengan kewajiban untuk mengelola sistem informasi desa. Kesalahan tata kelola ini menyebabkan beberapa website desa di kabupaten Gunungkidul yang kekurangan perangkat desa dan minim perangkat komputer membuat website desanya tidak up to date.

3) Konektivitas Internet dan Kepemilikan Perangkat Akses

Ketersediaan koneksi internet yang baik juga merupakan faktor yang mendorong minat warga untuk mengakses dan membaca artikel berita pada website desa. Namun, terbatasnya jumlah spot wifi internet umum membuat minat baca hanya terkonsentrasi bila sedang berada di balai desa, pos umum, tempat wisata yang memiliki spot wifi. Warga yang tidak dapat mengakses secara gratis akhirnya merasa tidak perlu mengakses website desa dengan menggunakan paket data yang dimiliki karena merasa mubajir dan harus menghemat kuota untuk browsing aplikasi dan informasi lainnya yang dirasa lebih penting.

Selain itu, tingkat kepemilikan smartphone juga faktor yang mempengaruhi minat baca. Masyarakat desa Nglanggeran merupakan warga rata-rata usia produktif yang 
memiliki smartphone untuk mengakses website desa sekitar 5 menit sekedar membaca informasi terbaru dan mengetahui perkembangan desa. Hal ini didukung oleh infrastruktur menara BTS sehingga kecepatan internet sangat baik. Kondisi ini berbanding terbalik dengan kondisi infrastruktur jaringan internet di desa Girijati dimana sebagian pedukuhan didominasi perkebunan dan permukiman jarang penduduk, kondisi jaringan telepon belum stabil dan koneksi sering terganggu sehingga menyebabkan warga enggan untuk mengakses website desa. Selain itu, pemahaman warga desa perihal pemanfaatan teknologi komunikasi masih rendah karena rata-rata warga masih dikategorikan masyarakat miskin dan rendah literasi digital.

Faktor Eksternal

1) Modal Sosial

Faktor eksternal yang menyebabkan peranan website desa sebelum memiliki efek afektif dan konatif adalah modal sosial. Dalam konteks komunikasi pembangunan desa, modal sosial ini berfungsi memberikan kemudahan akses informasi bagi masyarakat desa yang jarang mengakses website dengan cara menyampaikan informasi tepat guna kepada warga masyarakat rendah literasi secara langsung, dan modal sosial ini menjadi instrumen untuk memobilisasi sumber daya pada komunitas masyarakat untuk mencapai suatu tujuan.

Modal sosial ini berupa rasa tanggungjawab Penyelenggara desa seperti Kepala desa, Ketua RW/RT, dan perangkat lainnya untuk mengajak, menyampaikan informasi kepada warganya. Bentuk modal sosial lainnya adalah penyampaian berita dan informasi terkait dengan pembangunan masih dilakukan secara tradisional seperti pada pertemuan warga antar RT atau kegiatan PKK karena dirasa lebih komunikatif dan tepat sasaran. Penyampaian informasi tatap muka ini dirasakan lebih terbuka, menimbulkan rasa empati, dan ada dukungan dari orang sekitar yang ikut mendengarkan. Penerimaan bentuk kepercayaan yang tumbuh pada warga diawali oleh penerimaan warga tersebut dengan berbagi informasi dan bentuk empati kepedulian. Untuk menumbuhkan kepercayaan memerlukan pertukaran informasi yang jujur dan terbuka. Komunikasi intensif, melalui pertukaran informasi di antara warga memperkuat kepercayaan sehingga rasa percaya dan kepedulian terhadap sesama semakin kuat.

\section{2) Budaya Lisan}

Terdapat perilaku komunikasi pada masyarakat desa Nglanggeran dan desa Girijati yang lebih cenderung menggunakan tataran lisan melisan daripada tradisi bacatulis. Hal ini diperkuat oleh Tyasmara (2016) yang menyatakan bahwa dalam tradisi lisan terkandung kejadian-kejadian sejarah, adat istiadat, cerita, dongeng, peribahasa, lagu, mantra, nilai moral, dan nilai keagamaan. Perubahan budaya masyarakat yang seharusnya dari lisan kemudian ke tulisan lalu membaca dipengaruhi oleh perkembangan teknologi komunikasi dan informasi. Masyarakat desa Nglanggeran dan Girijati masih cenderung memiliki budaya lisan dibanding dengan budaya membaca dan menulis. Temuan di lapangan yang cukup unik adalah beberapa warga di Nglanggeran umumnya ingin langsung ke informasi yang diinginkan, membaca loncatloncat, dan menginginkan informasi yang berbeda, bermakna, dan relevan.

3) Misleading Kebijakan Pemerintah Daerah

Kesan teknokratis masih dominan dalam perancangan dan penyelenggaraan program SIDA karena diterjemahkan sekadar instrumen untuk menghimpun data. Program SIDA sebagai media akses informasi tidak dirancang untuk melahirkan proses komunikasi pembangunan yang memberdayakan masyarakat. Proses komunikasi- 
informasi mensyaratkan antarpihak melakukan komunikasi pembangunan. Dalam aktivitas komunikasi pembangunan, warga menempatkan kebutuhan informasi sebagai sumber kekuatan dan memilah informasi dan memproduksi informasi. Pengembangan website desa dengan berbagai konten atau informasi edukatif dan persuasif yang menunjang kebutuhan warga akan membantu pertumbuhan ke arah terbangunnya masyarakat informasi dalam lingkup perdesaan sehingga warga terlibat aktif untuk diskusi maupun negosiasi dalam proses-proses pengambilan keputusan publik di wilayahnya.

Berdasarkan uraian di atas, penelitian ini sejalan dengan penelitian sebelumnya yang telah dilakukan oleh Mulyawaty (2016) yang menyatakan bahwa website desa efektif sebagai media penyebaran informasi pembangunan dengan memenuhi dimensi-dimensi kualitas website dan peran internet opinion leader menjadi penting guna meningkatkan perkembangan isu-isu pembangunan dan popularitas website. Temuan pada penelitian ini juga memperkuat hasil dan saran penelitian yang dilakukan oleh Surahmi dan Farid (2018) yang menekankan bahwa perlu strategi komunikasi berbeda yang diterapkan oleh aparatur pemerintah Kecamatan Duampanua, Kabupaten Pinrang pada level strategi Message (pesan) agar terjadi peningkatan partisipasi masyarakat dalam pembangunan. Penelitian Muhammad Fikri Akbar, dkk (2019) juga menekankan bahwa perlu sosialisasi dengan pelaku pembangunan dalam bentuk penyebaran pesan oleh seseorang atau kelompok kepada publik untuk mengubah sikap, pendapat dan perilaku untuk meningkatkan kemajuan eksternal dan kepuasan internal dalam mencapai tujuan pembangunan.

Dengan demikian, pada era teknologi komunikasi dan informasi saat ini, pendekatan komunikasi pembangunan partisipatif dengan memanfaatkan teknologi komunikasi website sudah tepat digunakan untuk menumbuhkan sense of belonging terhadap kontribusi dan hasil pembangunan dan meningkatkan partisipasi masyarakat dalam tujuan peningkatan kualitas pembangunan.

\section{KESIMPULAN}

Website desa sebagai media komunikasi massa cukup efektif dalam melaksanakan tugas yang berberkaitan dengan pemerintahan. Namun website desa sebagai enabler komunikasi pembangunan belum mampu berperan sebagai media jurnalisme warga dimana masyarakat desa sendiri yang berperan aktif dalam mengumpulkan, melaporkan, menganalisis dan mendistribusikan berita dan informasi dan tugas itu diserahkan kepada perangkat desa. Data dan informasi yang dibagikan antar warga belum membentuk jurnalisme warga yang utuh karena konten artikel berita website desa tidak menarik, tidak signifikan, dan kurang berdampak dan mengedukasi masyarakat desa.

Selain itu, data dan informasi pembangunan pada kedua website desa belum membuat masyarakat merasa mampu untuk mengatur diri dalam membangun masyarakat, menghadapi tantangan, dan mengembangkan potensi desa karena sejatinya warga desa Nglanggeran dan Girijati mempunyai modal sosial seperti jejaring sosial dan rasa saling percaya memegang peranan penting dalam setiap proses dan perencanaan pembangunan desa. Oleh sebab itu, untuk memaksimalkan potensi penggunaan website desa maka dibutuhkan partisipasi warga dalam mengumpulkan, melaporkan, menganalisis dan menyebarluaskan berita serta informasi yang menyangkut kepentingan umum dan pelayanan publik. Jurnalisme warga yang merupakan kegiatan komunikasi pada ruang publik memungkinkan setiap warga untuk mengakses informasi dan membuka dialog secara terbuka menghasilkan inisiatif untuk proses perubahan yang diharapkan. 


\section{DAFTAR PUSTAKA}

Amin, M. (2018). ICT For Rural Area Development in Indonesia: A Literature Review. Journal of Information Technology and Its Utilization, Volume 1(Issue 2).

Andi Jaya Kasma. (2019). Partisipasi Masyarakat dalam Pembangunan Desa (Studi Perbandingan antara Desa terdekat (Desa Assorajang Kecamatan Tanasitolo) dan terluar (Desa Ongkoe Kecamatan Belawa) dari ibukota Kabupaten Wajo Sulawesi Selatan). Universitas Gadjah Mada.

Andi Surahmi, dan M. F. (2018). Strategi Komunikasi dalam Meningkatkan Partisipasi Masyarakat terhadap Pembangunan di Kecamatan Duampanua Kabupaten Pinrang. Jurnal Komunikasi Kareba, Volume 7 N.

Creswell, J. W. (2010). Research Design : Pendekatan Kualitatif, Kuantitatif, dan Mixed. Yogyakarta: Pustaka Pelajar.

George R. Terry. (1962). Office Management and Control (Fourth Edi). Illinois: Homewood Richard D. Irwin Inc.

Gordon B. Davis. (1974). Management Information System: Conceptual Foundation, Structure, and Development. Auckland: McGraw-Hill International Book Company.

Indrajit, R. E. (2011). Peranan Teknologi Informasi dan Internet. Yogyakarta: Andi Offset.

Johnson Alvonco. (2014). Practical Communication Skill, Sistem Komunikasi Model Umum dan Horenso Untuk Sukses Dalam Bisnis, Organisasi dan Kehidupan. Jakarta: Gramedia.

Meilyna Diah Anggrahini, Christina Rochayanti, dan E. A. S. (2008). Peran Humas Pemerintah Kabupaten Sragen dalam Pengelolaan ISI Informasi Website PEMDA Sebagai Media Communications Relations dengan Masyarakat. Jurnal Ilmu Komunikasi, Volume 6(Nomor 2), 145-151.

Muhammad Fikri Akbar, Erwin Putubasai, Asmaria, dan R. D. K. (2019). Peran Komunikasi dalam Pembangunan Masyarakat. Jurnal Komunika, Volume 2, https://doi.org/https://doi.org/10.24042/komunika.v2i2.6027

Mulyawaty, S. (2016). Efektivitas website Desa sebagai Media Penyebaran Informasi Pembangunan Informasi Pembangunan di Desa Malasari Kabupaten Bogor. Institur Pertanian Bogor.

Nurintan Cynthia Tyasmara. (2016). Kebijakan pengembangan koleksi perguruan Tinggi.

Pendit, P. L. (1992). Makna Informasi: Lanjutan dari Sebuah Perdebatan," dalam Kepustakawanan Indonesia: Potensi dan Tantangannya. (Antonius Bangun dkk, Ed.). Jakarta: Kesaint-Blanc.

Siti Irene. (2011). Desentralisasi dan Partisipasi Masyarakat dalam Pendidikan. Yogyakarta: Pustaka Pelajar.

Sugiyono. (2008). Metode Penelitian Kuantitatif Kualitatif dan R\&D. Bandung: Alfabeta.

Wulan Purnamawati. (2016). Hubungan Terpaan Berita Pemblokiran Situs Islam di Televisi terhadap Citra Kementerian Komunikasi dan Informatika pada Mahasiswa UIN Jakarta. Universitas Islam Negeri Syarif Hidayatullah, Jakarta. 